\title{
Месяцесловы богослужебных четвероевангелий львовской печати (XVII - XVIII веков)
}

\author{
Оксана Панкратьева \\ Chrześcijańska Akademia Teologiczna \\ Warszawa, Polska \\ oksanasun33@gmail.com
}

О. Панкратьева, Menologions of liturgical tetragospels from Lvov (XVII-XVIII c.), Elpis, 20 2018: 135-143.

О. Панкратьева, Menologiony tetraewangelii liturgicznych z oficyn lwowskich (XVII-XVIII w.), Elpis, 20 2018: 135-143.

\begin{abstract}
Textological research early printed Cyrillic tetragospel menologions (i.e. the "fixed year" of the liturgical calendar) has shown that they contain some textual variants and liturgical peculiarities inherited from manuscript tradition, as well as other unique elements that are characteristic only for specific local traditions.

Research of four months (September - December), conducted on 76 early printed tetragospels (out of all 120), including all eight tetras issued in Lvov in XVI and XVIII century, proved the possibility of grouping them into several small groups on the above-mentioned textological and liturgical peculiarities. The article presents all the unique features characteristic only for all the Lvov tetragospels, as well as for one subgroup (consisting of two Gospels) that can be derived from them.

The results of this research also shed some light on the processes of formation and development, and the mutual influences of various Cyrillic printing and liturgical traditions
\end{abstract}

\begin{abstract}
Streszczenie: Badania tekstologiczne menologionów (tzn. części minejnej kalendarza liturgicznego) starych druków cyrylickich tetraewangelii poświadczyły istnienie w nich pewnej liczby wariantów tekstu i osobliwości liturgicznych. Są one odbiciem starszej rękopiśmiennej lub lokalnej tradycji sakralnej.

Badania czterech miesięcy (wrzesień - grudzień) 76 (spośród wszystkich 120) starych druków tetraewangelii, włącznie ze wszystkimi ośmioma tetrami wydanymi we Lwowie w XVII i XVIII wieku, potwierdziły możliwość podzielenia cyrylickich Ewangelii na podstawie wariantów tekstowych oraz osobliwości liturgicznych na kilka grup. W artykule zostały przedstawione elementy charakterystyczne wyłącznie dla wszystkich tetraewangelii lwowskich w tym wydzielonej jednej podgrupy składającej się z dwóch wydań.

Wyniki niniejszego badania ukazują w pewnym stopniu proces formowania się i ewolucji oraz wzajemnych wpływów różnych druków cyrylickich oraz tradycji liturgicznych.
\end{abstract}

\begin{abstract}
Аннотация: Текстологическое исследование Месяцесловов (т.н.з. минейной части литургического календаря) старопечатных кириллических тетраевангелий обнаружило существующее в них определенное количество текстовых разночтений и литургических особенностей. Эти разночтения либо унаследованы из рукописного текста, либо являются отражением особенностей поместных церквей.

Исследования четырех месяцев (сентябрь - декабрь) 76 (из 120 сохранившихся) старопечатных тетраевангелий, включая восемь тетров, изданных во Львове в XVII-XVIII веках, подтвердили возможность группирования кириллических Евангелий на основе текстовых разночтений и литургических особенностей. В статье показаны элементы, характерные только для львовских Евангелий, среди которых выделяется подгруппа из двух изданий.

Результаты проведенного исследования в некоторой степени показывают процесс формирования, развития, а также взаимовлияния кириллических изданий, имеющих свои литургические особенности.
\end{abstract}

Keywords: early printed tetragospels, menologion, Lvov, textology, liturgical tradition

Słowa kluczowe: stare druki, tetraewangelia, Menologion, Lwów, tekstologia, tradycja liturgiczna

Ключевые слова: старопечатные тетраевангелия, Месяцеслов, Львов, текстология, литургические особенности

Всестороннее изучение полной традиции церковнославянского Евангелия, и рукописной и печатной, еще ждет своего времени. Рукописные тетраевангелия в славянском переводе исследовались лишь частично: либо избранные фрагменты текстов одной Евангельской книги, либо добавочные части до основного текста.

Так, для изданий четырех ${ }^{1}$ «Евангелий в славян-

В настоящее время изданы только два Евангелия: Евангелие от Иоанна в славянской традищии (в 1998 г.) и Евангелие от Матфея в славянской традиции (в 2005 г.). Два остальные Евангелия готовы к печати. ской традиции» текстологический анализ рукописей проводился только на основе литургического чтения первого страстного Евангелия (И 13,31-18,1)2 и двух чтений Евангелия от Матфея на восьмое $(14,14-22)$ и девятое $(14,22-34)$ воскресение по Пятидесятнице ${ }^{3}$.

В результате исследования составителями принято решение, что в критическом аппарате, пока единственного такого издания, будут даны разночтения около

\footnotetext{
2 Евангелие от Иоанна, 1998, 9 (І. пагин).

3 Евангелие от Матфея, 2005, 163.
} 
$30^{4}$ источников ${ }^{5}$, из которых только один является текстом старопечатного Евангелия - это часть Острожской Библии, напечатанной в 1581 году.

Текстологический анализ части литургических чтений Пасхального периода и после праздника Пятидесятницы в Евангелиях от Иоанна и Матфея всех кратких рукописных апракосов был проведен Е. Остапчуком. ${ }^{6}$ Однако данные, опубликованные в двух его монографиях, не содержат окончательных выводов проведенного им исследования текста Евангелия ${ }^{7}$.

Определенный интерес представляют исследования А. Альберти, основанные на т.н. узлах разночтений в славянской традиции ${ }^{8}$, принципы которого были недавно опубликованы в журнале Studii Slavistici, ${ }^{9}$ где он также сообщил о подготовке издания всех четырех Евангелий.

Вопросу добавочных текстов, находящихся в рукописных Евангелиях, уделено внимание в трудах Е. Дограмаджиевой. Основываясь на исследовании почти $200^{10}$ рукописных богослужебных четвероевангелий, она указывает на наличие в них до сорока различного рода дополнительных текстов.

Помимо Е. Дограмаджиевой ${ }^{11}$ и других ученых, ${ }^{12}$ детальным исследованием месяцесловов рукописных славянских Евангелий в последние время ${ }^{13}$ занималась О. Лосева. Ей принадлежит монументальная ${ }^{14}$ работа, ${ }^{15}$ основанная на исследовании 152 рукописных Евангелий, датируемых XI-XIV в. ${ }^{16}$

Из этого краткого обзора видно, что рукописные церковнославянские Евангелия уже длительное время ${ }^{17}$ находятся в зоне интереса ученых различных направлений.

Иначе обстоит дело со старопечатными и печатными Евангелиями, унаследовавшими тексты из руко-

\footnotetext{
4 Часть Евангелия от Иоанна исследована на основе более чем 1000 рукописей (Евангелие от Иоанна, 1998, 79 (I. пагин); Евангелие от Матфея, 2005, 7), а Ев. от Матфея более чем 500 (Евангелие от Матфея, 2005, 163).

Перечень источников см. Евангелие от Иоанна, 1998, 39-40 (I. пагин); Евангелие от Матфея, 2005, 9-10.

6 Ostapczuk, 2010; 2013.

В первой монографии дан текстологический аппарат только трёх литургических чтений (Ostapczuk, 2010, с. 263-283), а во второй шести (Ostapczuk, 2010, 489-576).

8 Альберти, 2016, 308.

Альберти, 2016, 307-335.

- Дограмаджиева, 1993, 3.

Дограмаджиева, 2010

12 Перечисление ученых занимавшихся исследованием месяцесловов рукописных евангелий см. Ostapczuk, 2016a, 66.

13 Перечень древнейших исследований месяцесловов см. Иванова, 2010, 108-114; Ostapczuk, 2016a, 66.

14 Монументальной работой по исследованию месяцесловов является и трехтомная работа архиепископа Сергея (Сергий архиепископ, 1901).

15 Иные работы О. Лосевой посвященные изучению месяцесловов см. Лосева, 1995, 46-54; 1999a; 1999b, 5-59; 2003, 132-141.

16 Лосева 2001а.

17 Можно указать на работы архимандрита Амфилохия $(1882 ; 1883)$ или Г.А. Воскресенского (1894; 1896).
}

писной традиции. Четвероевангелия ${ }^{18}$ и апракосы ${ }^{19}$, как и другие части Священного Писания, печать которых началась со второй половины XVI в., текстологически исследовались намного реже и непоследовательно ${ }^{20}$.

Такое предварительное текстологическое изучение отдельных частей старопечатного церковнославянского текста апракосов ${ }^{21}$ и четвероевангелий начато Е. Остапчуком. В Евангелии от Матфея было исследовано шесть ${ }^{22}$ зачал в 23 изданиях ${ }^{23}$, а в Евангелии от Марка девять первых зачал уже в 75 изданиях. ${ }^{24}$ Однако, анализ даже небольшой части евангельского текста старопечатной традиции позволил ему предварительно распределить исследуемые тетры на несколько групп ${ }^{25}$.

Богослужебные четвероевангелия содержат т.н. литургический аппарат, без которого невозможно их использование в богослужении. Это указатель рядовых чтений на каждый день седмицы всего года Gказа́мїє

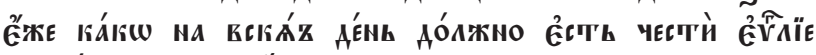

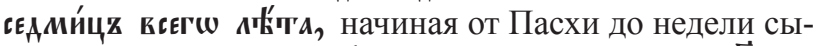

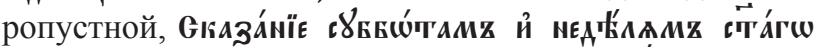

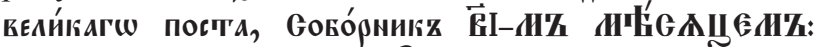

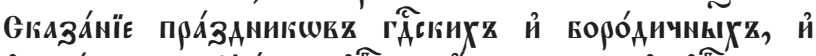

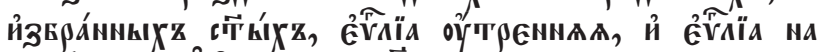

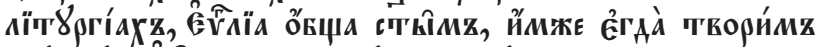

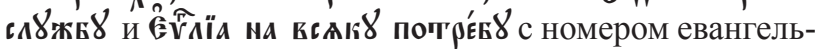
ского зачала, помещенного непосредственно в тексте Евангелия или на полях листов.

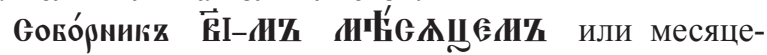
словы старопечатных (т.е. выпущенных с 1512 по 1800 гг.) и печатных (т.е. выпущенных после 1801 г.) четвероевангелий не исследовались совсем. Детальное их изучение способствовало бы лучшему пониманию истории формирования и развития кириллического книгопечатания, вобравшего в себя не только опыт составления и редактирования богослужебных книг, но и унаследовавшего неточности древних рукописей. Такие исследования важны с исторической, богословской, книговедческой и др. точек зрения. Настоящая статья является пробой заполнить в какой-то мере этот пробел.

Изданное в 1512 году в Тырговиште, в то время столице Валахии, первое богослужебное тетроевангелие послужило развитию сербской и угровлахийской традиции кириллической печати евангельского текста немногим более, чем на полстолетия. В середине XVI

\footnotetext{
18 Перечень старопечатных церковнославянских четвероевангелий см. Ostapczuk, 2013, 137-148.

19 Перечень старопечатных церковнославянских апракосов (с краткой характеристикой) см. Ostapczuk, 2013, 155-164.

20 Так например, Ф.К. Людоговский исследовал изменения текста Евангелия от Иоанна в четвероевангелиях II пол. XVII - нач. XVIII вв. московских изданий 1651, 1653, 1663, 1668 и 1703 гг. (Людоговский, 2006, 411-414), а М. Курянович только киевское четвероевангелие 1771 (Kurianowicz, 2005, 287-302; 2010, 127-131; 2012, 167-176).

21 Cм. Ostapczuk, 2011, 87-106; 2014, 10-24.

22 См. Ostapczuk, 2016b, 279.

23 Ostapczuk, 2016b, 275-286

24 Ostapczuk, 2017a.

25 Ostapczuk, 2016b, 283-284.
} 
века началось формирование московской традиции, основанной на отечественном рукописном наследии. На территории Великого княжества Литовского первый богослужебный тетр, напечатанный в Вильно в 1575 году, стал образцом не только для двух последующих виленских изданий 1600 и 1620 годов, но и для более поздних изданий литовской, украинской и московской печати ${ }^{26}$. Во Львове первое Евангелие было напечата-

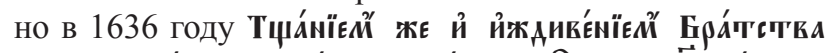

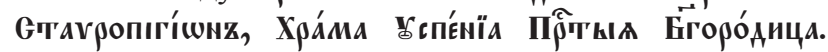
Высоким полиграфическим качеством и художественным оформлением отличались Евангелия издаваемые с 1697 года в типографии Киево-Печерского монастыря. Четыре Евангелия на протяжении XVIII века были напечатаны в Почаевском монастыре. Принято считать, что монастырская типография была основана Иовом Почаевским в начале XVII века, хотя о точном времени ее становления ученые так и не пришли к единому мнению. $^{27}$

На сегодняшний день известно 120 изданий богослужебных тетроевангелий периода XVI-XVIII веков ${ }^{28}$, в основе которых, как считается, лежит устоявшийся Евангельский текст, вытеснивший другие разновидности, называемые «вульгатой». ${ }^{29}$ Сопоставление текстов не только древних рукописей ${ }^{30}$ но и старопечатных Евангелий, обнаруживает текстологические и литургические отличия, по которым они разделяются или объединяются в группы ${ }^{31}$. Поскольку настоящая статья посвящена исследованию месяцеслова, автором был проведен сравнительно-текстологический анализ месяцесловов 76-ти старопечатных кириллических богослужебных Евангелий XVI - XVIII веков ${ }^{32}$, т.е. более половины всех источников.

Месяцеслов, в котором соответствующие тексты, т.е. литургические указания, расположены в порядке следования дней и месяцев года с 1 сентября по 31 августа ${ }^{33}$, помещен в конце богослужебного Евангелия. Он является наиболее изменяемой его частью ввиду постоянного расширения календарного состава и реак-

\footnotetext{
26 Бондар, 2015, 109-112.

Тиховский, 1895, 1-8.

Ostapczuk, 2013, 137-148; 2016b, 279.

Евангелие от Иоанна, 1998, 17 (І пагин.).

Жуковская, 1976, 35.

Ostapczuk, 2016b, 283-284.

32 Исследованные тетры были изданы в: Тырговище в 1512 г.; Руяне в 1537г;; Сибиу в 1546 г.; Белграде в 1552 г;; Брашове в 1561/62 г.; Мрькшиной Церкви в 1562 г.; Вильнюсе в 1575, 1600 (без сигнатур), около 1620 (с сигнатурами), 1644 гг; Шебеше в 1579 г.; Шебеше или Брашове в 1583 г.; Львове в типографии Успенского Братства в 1636, $1644,1670,1690,1704,1722,1743$ гг. и в типографии Михаила Сльозки в 1665 г.; Киеве в 1697, 1712, 1733, 1746, 1752, 1759, 1771, 1773 и 1784 гг; Почаеве в 1759, 1768, 1771, 1780 гг;:Нижнем Новгороде 1613 г., Клинцах 1786г., Москве, 40 изданий, в 1553/54 (узкошрифтное), 1558/59 (среднешрифтное), 1563/64 (широкошрифтное), 1606, $1627,1628,1637,1640,1644,1648,1651,1657,1663,1668,1681,1685$, $1688,1689,1694,1703,1716,1717,1744,1745$, марте 1748, 1753, 1762 , январе и мае $1771,1774,1775$, июне и августе $1779,1784,1785$, 1786, сентябре и ноябре 1789, 1791 и 1796 гг. О датировке и месте издания см. Ostapczuk, 2013, 137-148.

33 Жуковская, 1976, 6.
}

ции на смену церковного Устава ${ }^{34}$ и может иметь свои особенности в поместных церквях.

Исследования проводились на примере первых 4-х месяцев, начиная с 1 сентября (Нача́ло їди́́sта,

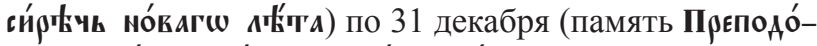

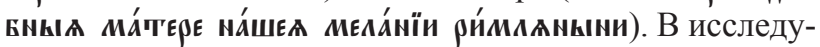
емый период вошли четыре двунадесятых праздника:

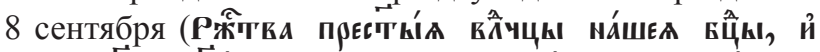

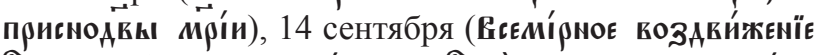

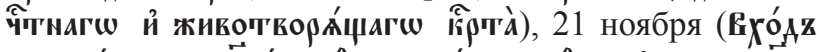

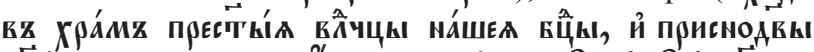

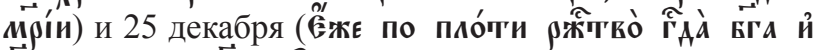

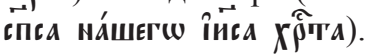

Следует отметить, что месяцесловы старопечатных богослужебных Евангелий более унифицированы и похожи между собой, нежели месяцесловы древних рукописей ${ }^{35}$. По обнаруженным особенностям сходств или различий месяцесловы исследуемых церковнославянских Евангелий XVI-XVIII веков условно можно разделить на несколько групп: а) месяцесловы Евангелий южнославянских XVI в., первых трех виленских Евангелий $(1575,1600,1620$ гг.) и московских XVI середины XVII веков; б) месяцесловы Евангелий московских середины XVII до конца XVIII века; в) почаевских XVIII века; г) киевских XVII-XVIII веков; д) львовских XVII-XVIII веков.

Данная работа не включает в себя культурно-исторический и литургический анализ развития месяцесловов старопечатных Евангелий. В исследовании отмечен пока только факт наличия текстовых разночтений и особенностей изданий, таких как:

- отсутствие дня месяца;

- присутствие либо отсутствие упоминания о памяти святого (имеются ввиду святые первых веков христианства, празднуемые всей полнотой Церкви, поскольку дни памяти мучеников праздновались еще в первые века, не только в тех церквах, к которым принадлежали, но и в других ${ }^{36}$ );

- расхождения в изложении имени и чина святости празднуемых святых;

- расхождения в нумерации зачал литургических евангельских чтений;

- присутствие указаний на чтение Евангелий на утрени;

- присутствие дополнительных богослужебных указаний;

- различия в определении зачало - глава в литургических указаниях евангельских чтений;

- присутствие или отсутствие слов ма мїтургі́n, зача́ло, частицы 6 в литургических указаниях евангельских чтений.

Некоторые различия не представляется возможным систематизировать. В основном, это касается присут-

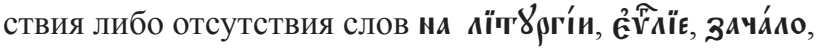

\footnotetext{
34 Лосева, 2001b, 15.

35 Лосева, 2001b, 14-35.

36 Сергий архиепископ (Спасскій), 1901 (Т. 1), 9.
} 
частицы ш в литургических указаниях евангельских чтений. И, если отсутствие слова ма иїт8ргі́n является более правилом нежели исключением, то присутствие

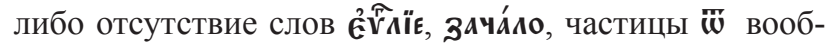
ще не имеет системности. Очевидно, что те последние разночтения не содержат особого богослужебного или исторического значения так же, как и отсутствие союза й и могут представлять собой всего лишь возможные технические издержки при печати.

Во Львове Евангелия были изданы ${ }^{37}$ в типографии Успенского Братства в 1636, 1644, 1670, 1690, 1704,

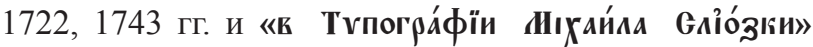
в 1665 г. Всего лишь восемь раз. Несмотря на многочисленные исторические исследования о деятельности Успенского Братства и его типографии во Льво-

37 Ostapczuk, 2017b, 181-189. ве, сейчас мы не располагаем сведениями о каких-то конкретных источниках (т.е. рукописях или изданиях), которыми пользовались справщики типографии при подготовке евангельского текста к печати. Указание на древнегреческие источники содержится в самом Еван-

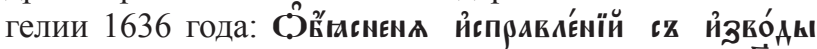

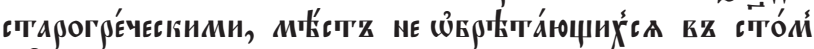

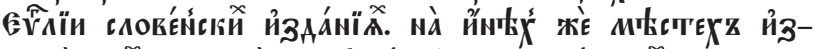

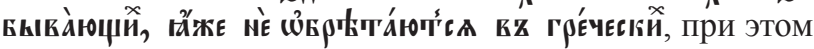
неизвестно, были ли они подлинниками при составлении месяцеслова. В любом случае, исследование части литургического аппарата доказало, что львовские старопечатные тетроевангелия выделяются среди остальных исследуемых богослужебных печатных Евангелий периода XVI-XVIII веков и характерные для них отличия можно объединить по категориям:

а) присутствие дополнительных богослужебных указаний:

\begin{tabular}{|c|c|c|}
\hline День & $\begin{array}{c}\text { Форма, принятая в большинстве } \\
\text { исследуемых Евангелий }\end{array}$ & $\begin{array}{c}\text { Форма, установленная во львовских Евангелиях } \\
1636,1644,1665,1670,1690,1704,1722,1743 \text { гг. }\end{array}$ \\
\hline 1 сентября & 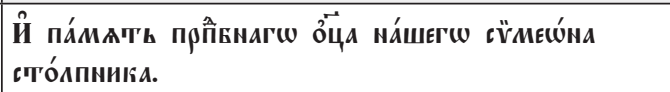 & 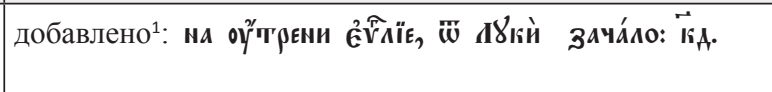 \\
\hline 6 сентября & 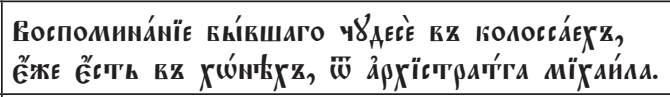 & 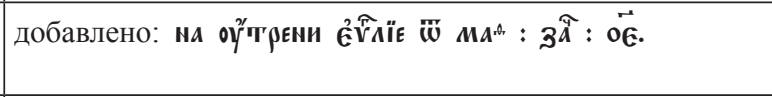 \\
\hline 18 сентября & 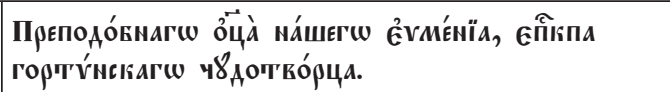 & 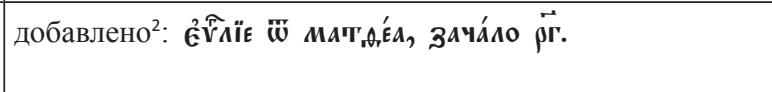 \\
\hline 14 октября & Й ПрЕПодо́кнLІа параскі́́์ & 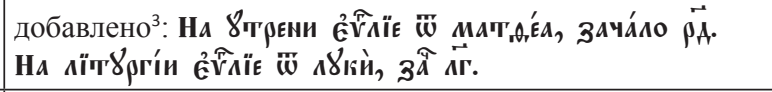 \\
\hline 1 ноября & 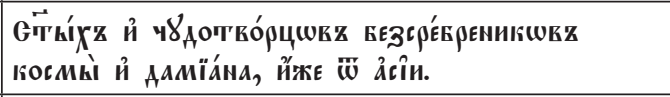 & 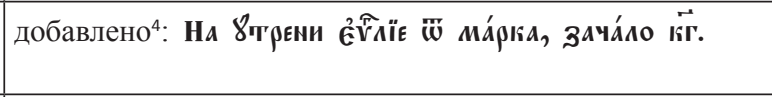 \\
\hline 11 ноября & 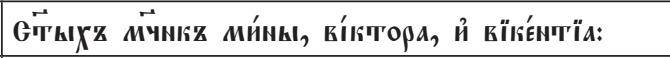 & 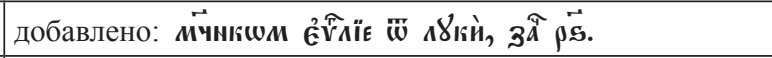 \\
\hline 1 декабря & 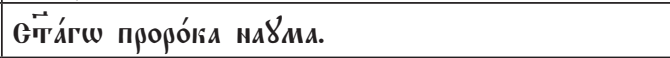 & 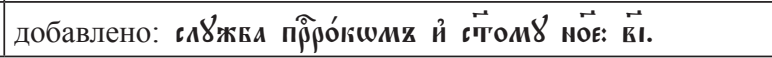 \\
\hline
\end{tabular}

б) изложение праздника, чина святости или имени святого:

\begin{tabular}{|c|c|c|}
\hline День & $\begin{array}{c}\text { Форма, принятая в большинстве } \\
\text { исследуемых Евангелий }\end{array}$ & $\begin{array}{c}\text { Форма, установленная во львовских Евангелиях } \\
1636,1644,1665,1690,1704,1722,1743 \text { гг. }\end{array}$ \\
\hline & 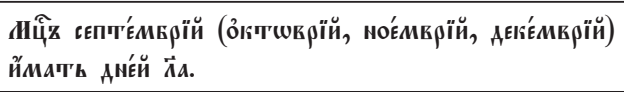 & 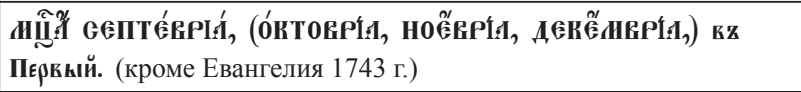 \\
\hline 1 сентября & 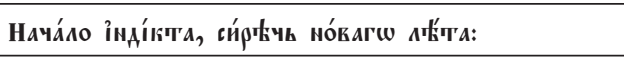 & 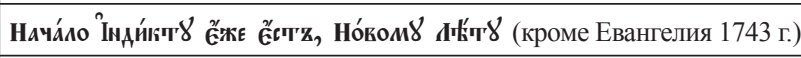 \\
\hline 5 сентября & 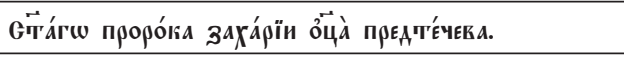 & 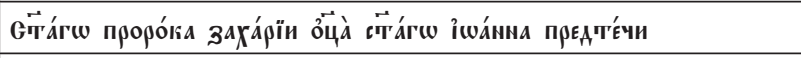 \\
\hline 14 сентября & 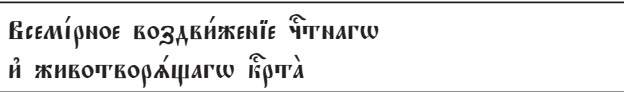 & 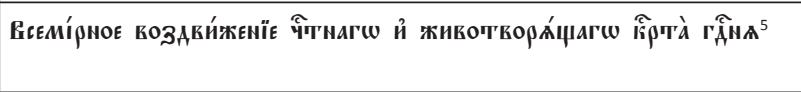 \\
\hline 23 сентября & 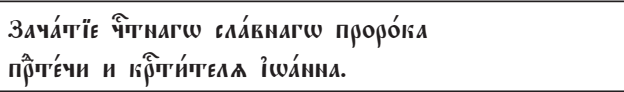 & 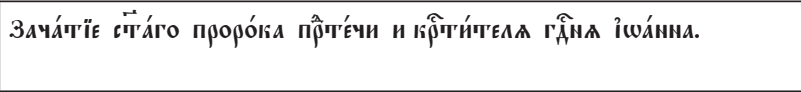 \\
\hline 1 октября & 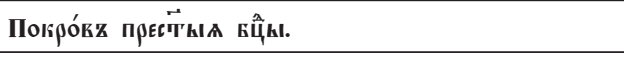 & 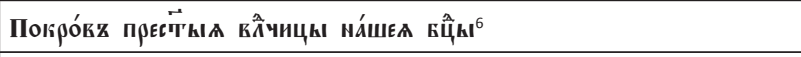 \\
\hline 11 октября & 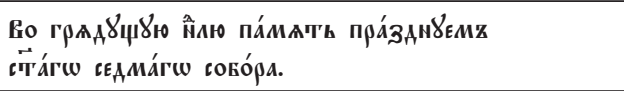 & 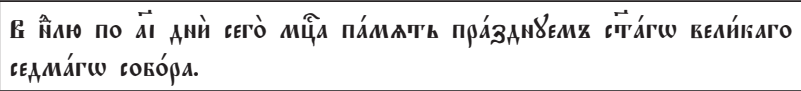 \\
\hline 14 октября & й прєподо́кным параскі́́์Vи. & 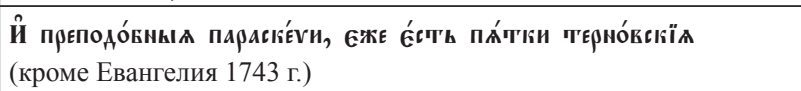 \\
\hline
\end{tabular}




\begin{tabular}{|c|c|c|}
\hline 28 октября & 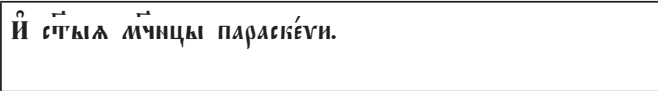 & 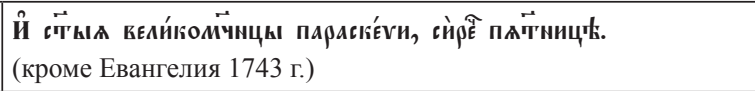 \\
\hline 7 ноября & 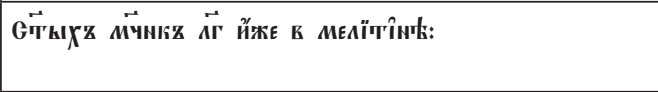 & 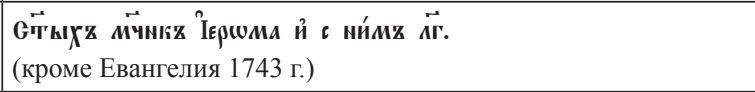 \\
\hline 7 ноября & 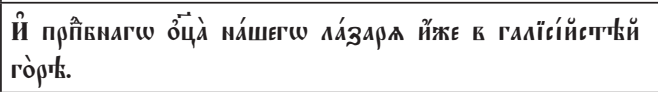 & 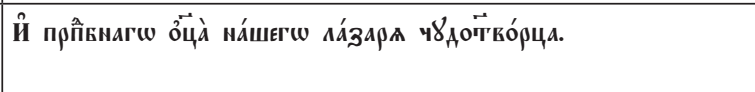 \\
\hline 11 ноября & 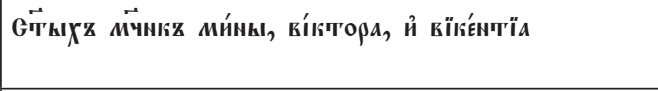 & 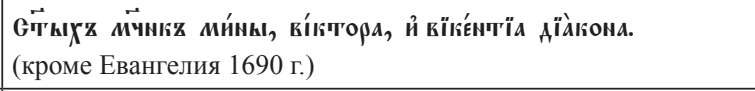 \\
\hline 14 ноября & 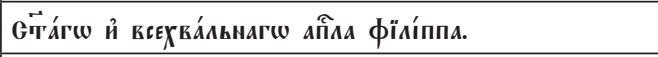 & 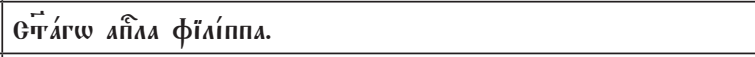 \\
\hline 16 ноября & 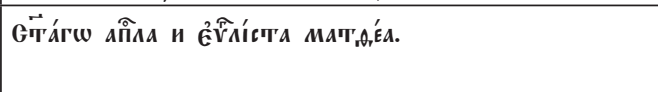 & 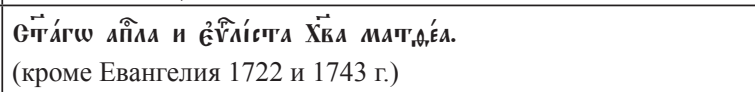 \\
\hline 5 декабря & 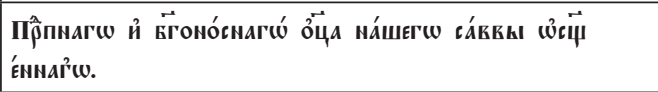 & 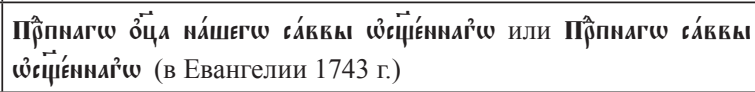 \\
\hline 13 декабря & 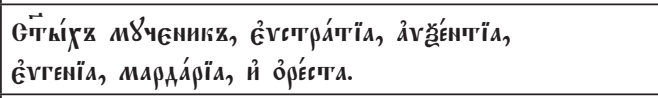 & 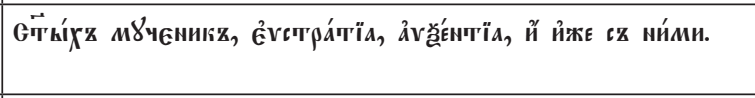 \\
\hline 21 декабря & 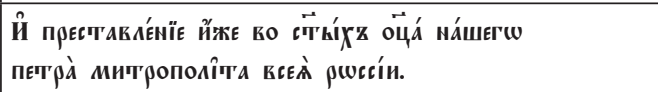 & 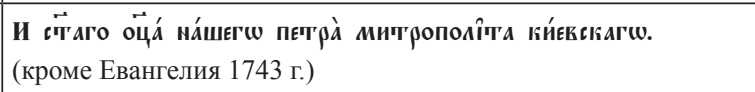 \\
\hline 27 декабря & 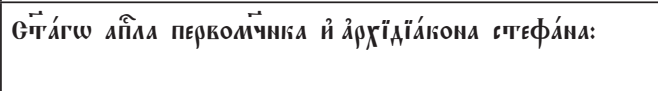 & 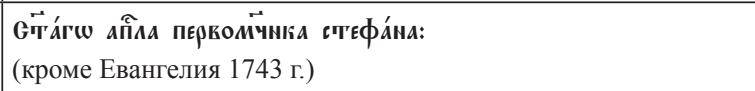 \\
\hline
\end{tabular}

в) расхождения в чтениях литургических Евангелий:

\begin{tabular}{|c|c|c|}
\hline День & $\begin{array}{c}\text { Форма, принятая } \\
\text { в большинстве исследуемых } \\
\text { Евангелий }\end{array}$ & $\begin{array}{c}\text { Форма, установленная во } \\
\text { львовских Евангелиях 1636, 1644, } \\
\text { 1665, 1690, 1704, } 1722 \text { и } 1743 \text { гг. }\end{array}$ \\
\hline 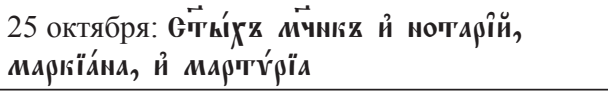 & 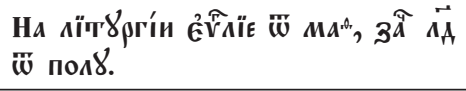 & 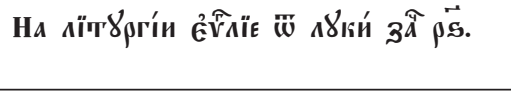 \\
\hline 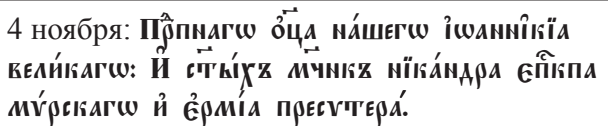 & 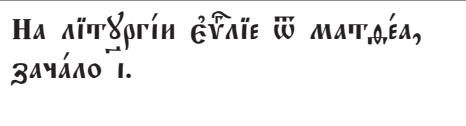 & 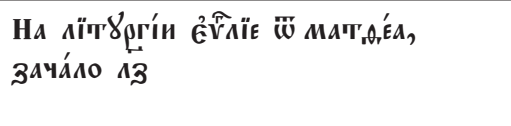 \\
\hline
\end{tabular}

г) отсутствия дня в Месяцеслове:

\begin{tabular}{|c|c|c|}
\hline 15 ноября & 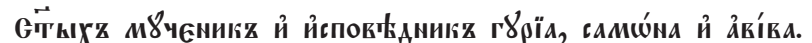 & во львовских Евангелиях день отсутствует \\
\hline
\end{tabular}

Дополнительно во львовские тетроевангелия под

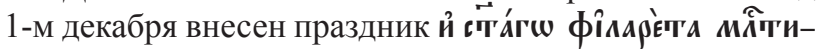
каго, который присутствует также в трех московских Евангелиях 1657, 1663 и 1681 гг., но отсутствует во львовском тетре 1743 г., а также под 26-м декабря

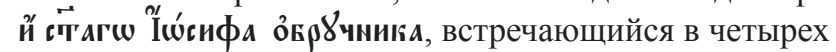
более поздних почаевских изданиях 1759, 1768, 1771 и 1780 гг.

Продолжение исследования, возможно, укажет, какими именно подлинниками пользовались печатники типографий. Ведь могли быть использованы рукописные месяцесловы не только Евангелий, но и Апостолов, Обиходников, Часословов. Так, память Филарета Милостивого под 1 декабря указана в месяцеслове Апостола конца XIV - начала XV вв., а Иосифа Обручника - под 26 декабря в Апостоле начала $\mathrm{XV}$ в., в то время, как в большинстве рукописных Евангелий XI-XIV веков память прав. Иосифа Обручника, царя Давида и ап. Иакова, брата Господня указана как переходящее празднование, отмечаемое в ближайший воскресный день после Рождества Христова. ${ }^{38}$

А сходство в чтениях, как было указано выше (сноски №№ 38-43), со старопечатными Евангелиями киевской (двумя первыми), московской (некоторыми) и почаевской печати подтверждает взаимовлияние типографских традиций.

Некоторые отличия от всех львовских Евангелий имеет тетр 1743 г. В его месяцеслове не выявлено большого количества особенностей характерных львовским изданиям четвероевангелий. Поэтому уместно говорить о корректурных правках этой - изданной в 1743 году - богослужебной Евангельской книги. Основные разночтения касаются отличий в изложении праздников, чина святости и имени святых:

\footnotetext{
38 Лосева, 2001a, 214, 231-232.
} 


\begin{tabular}{|c|c|c|c|}
\hline & День & $\begin{array}{c}\text { Форма, принятая в большинстве исследуемых } \\
\text { Евангелий }\end{array}$ & $\begin{array}{c}\text { Форма, установленная только } \\
\text { во львовском Евангелии } 1743 \text { г. }\end{array}$ \\
\hline \multirow{6}{*}{ 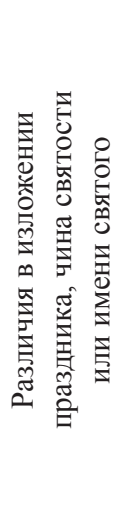 } & & 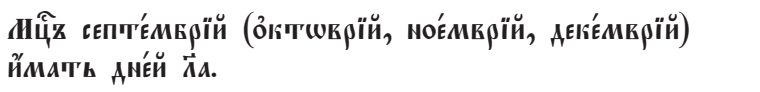 & опущено ймат'Һ дам'́й \\
\hline & 1 сентября & 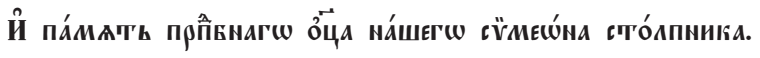 & опущено па́мАт'и \\
\hline & 13 сентября & 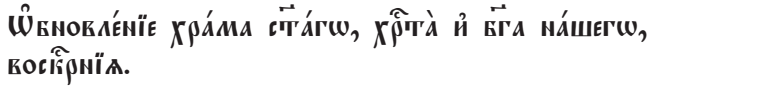 & 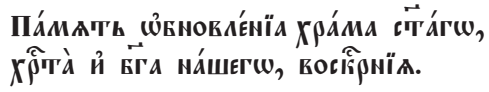 \\
\hline & 13 сентября & 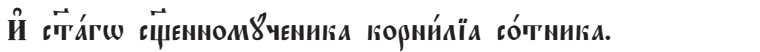 & опущено ст'т́́гw \\
\hline & 11 ноября & 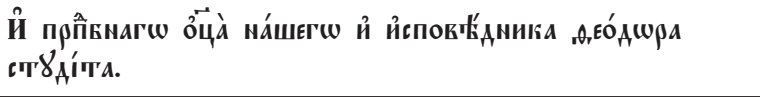 & 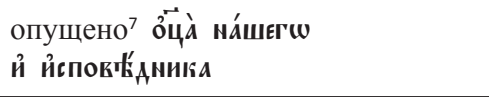 \\
\hline & 12 декабря & 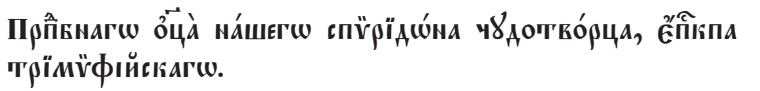 & опущено ч8дотко́рца \\
\hline 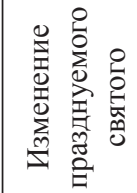 & 4 октября & 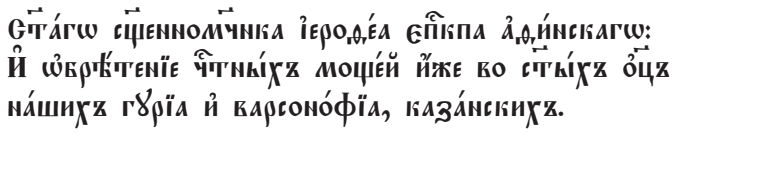 & 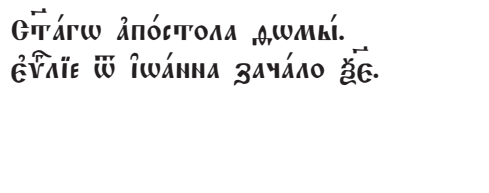 \\
\hline 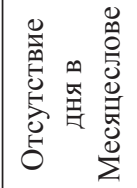 & 6 октября & 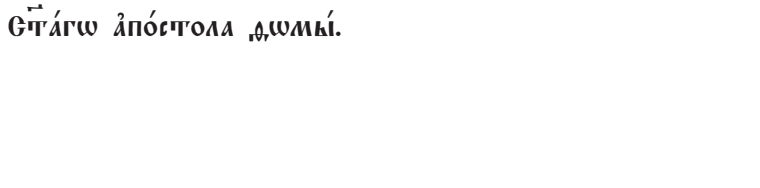 & $\begin{array}{l}\text { день отсутствует, в то время как он } \\
\text { есть во всех львовских тетрах }\end{array}$ \\
\hline
\end{tabular}

Евангелия 1644 г. (подготовленное по заказу Успенского Братства) и 1665 г., изданные Михаилом Слезкой, содержат весьма значительные отличия не только от других львовских тетров, но и от всех остальных исследуемых старопечатных церковнославянских Евангелий.

\begin{tabular}{|c|c|c|c|}
\hline $\begin{array}{l}\text { Выявленные } \\
\text { расхождения }\end{array}$ & День & $\begin{array}{c}\text { Форма, принятая в большинстве } \\
\text { исследуемых Евангелий }\end{array}$ & $\begin{array}{c}\text { Форма, установленная только во львовских } \\
\text { Евангелиях } 1644 \text { и } 1665 \text { гг. }\end{array}$ \\
\hline \multirow{2}{*}{ 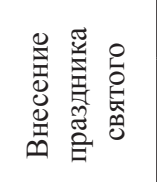 } & 1 сентября & пропущено & 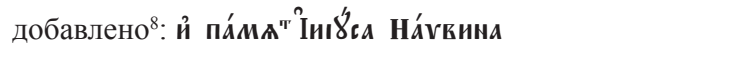 \\
\hline & 3 сентября & пропущено 9 & добавлено: Й прйнагш ӧца їша́нна по́ст'ника \\
\hline \multirow{7}{*}{ 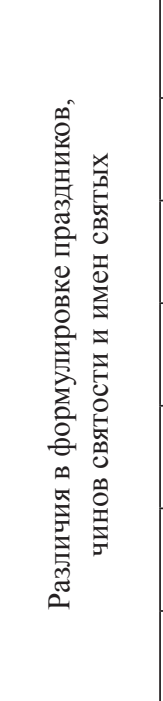 } & 1 сентября & 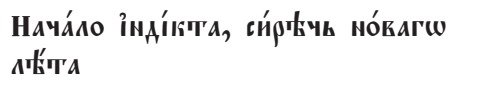 & 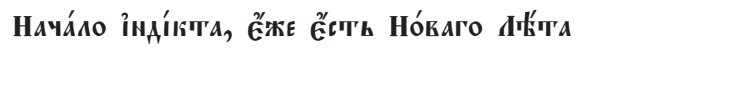 \\
\hline & 1 сентября & 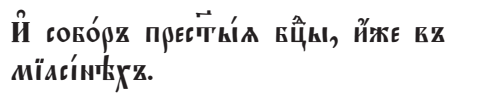 & 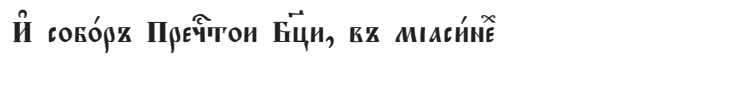 \\
\hline & 2 сентября & 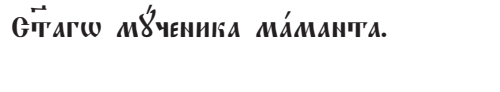 & 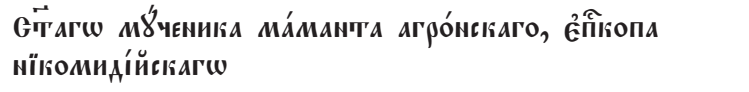 \\
\hline & 4 сентября & 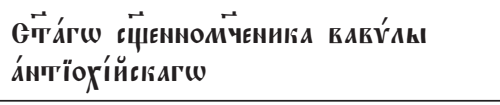 & 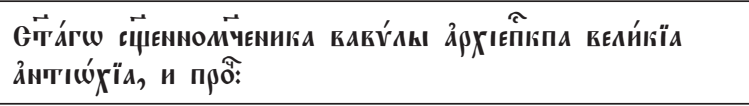 \\
\hline & 4 сентября & 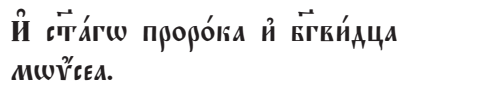 & 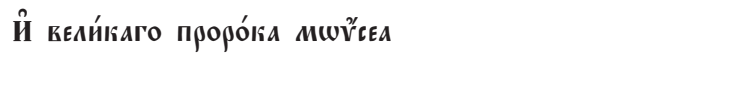 \\
\hline & 20 сентября & 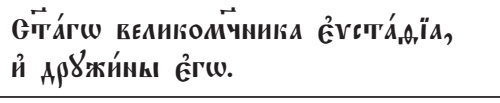 & 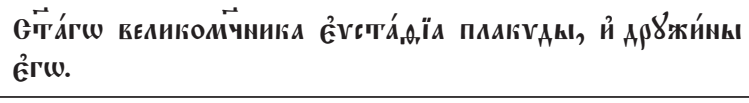 \\
\hline & 22 ноября & 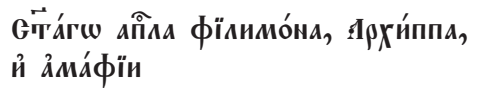 & 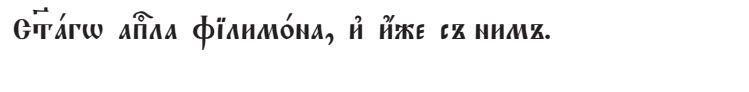 \\
\hline
\end{tabular}




\begin{tabular}{|c|c|c|c|}
\hline \multirow{4}{*}{ 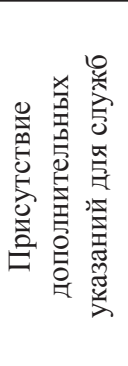 } & 17 сентября ${ }^{10}$ & 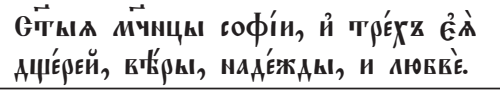 & 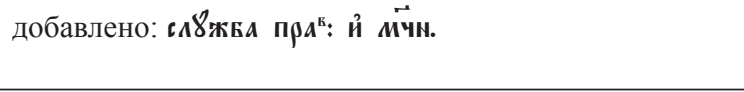 \\
\hline & 20 сентября & 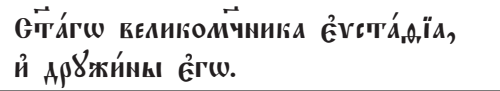 & добавлено ${ }^{11}:$ На 岁т \\
\hline & 23 сентября & 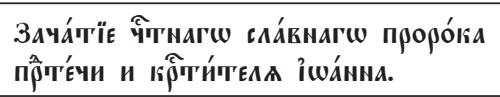 & 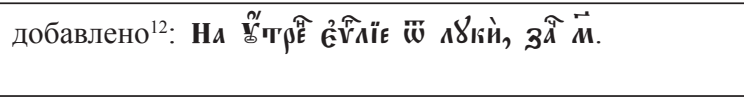 \\
\hline & 27 декабря & 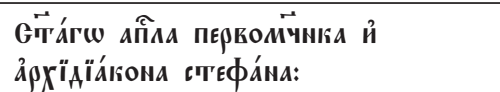 & 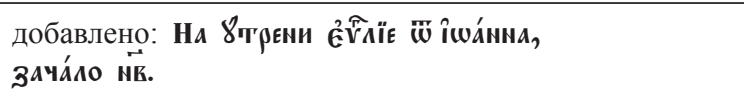 \\
\hline \multirow{5}{*}{ 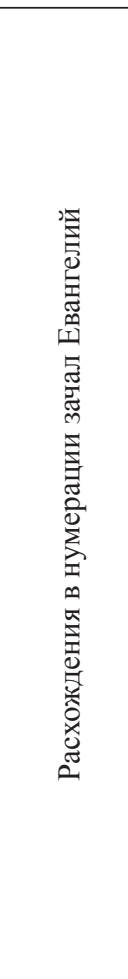 } & 6 ноября & 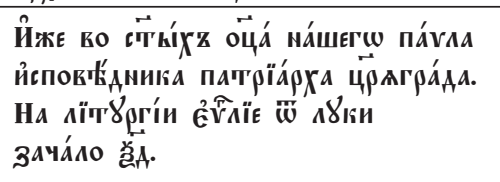 & 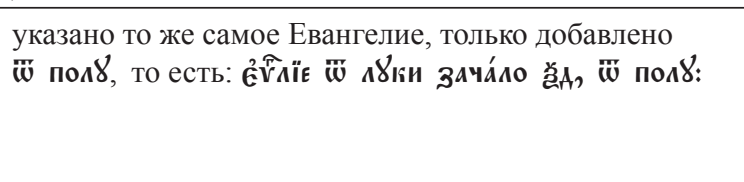 \\
\hline & 17 декабря & 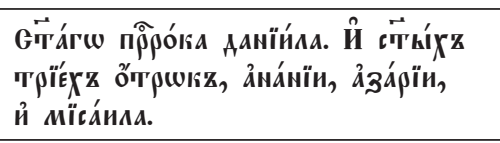 & 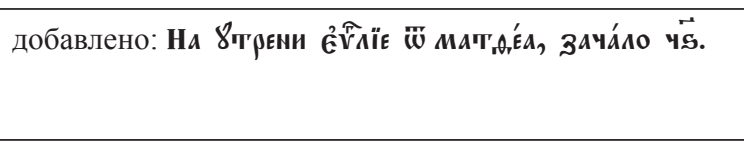 \\
\hline & 24 декабря & 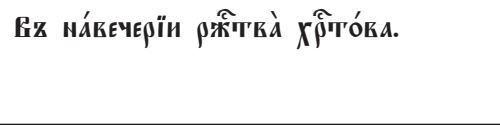 & 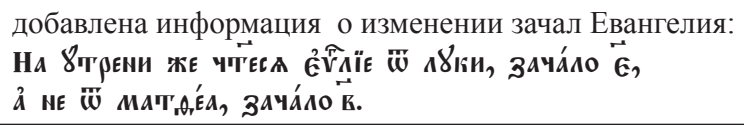 \\
\hline & 26 декабря & 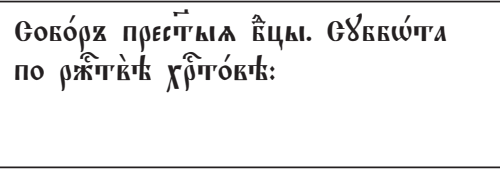 & 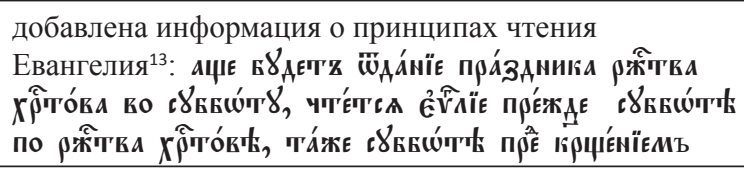 \\
\hline & & 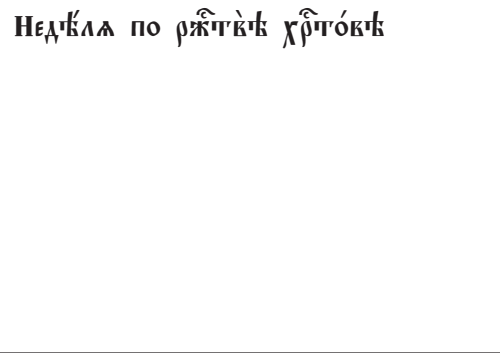 & 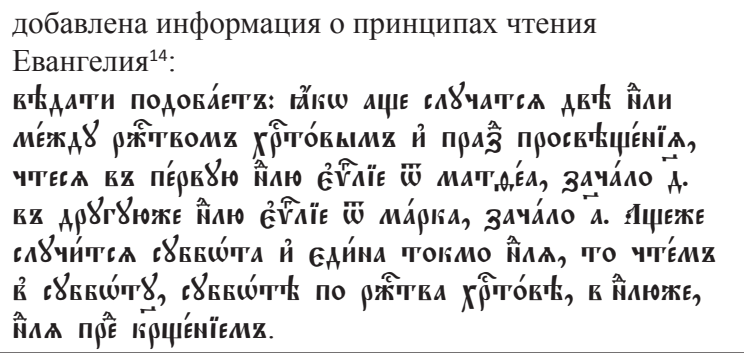 \\
\hline \multicolumn{4}{|c|}{$\begin{array}{l}8 \text { Также в московских евангелиях 1685, } 1688 \text { и } 1694 \text { гг; }{ }^{9} \text { Возможно, это сделано по ошибке, поскольку в большинстве евангелий память } \\
\text { внесена } 2 \text { сентября; }{ }^{10} \text { Этого дня - } 17 \text { сентября - нет во всех остальных львовских Евангелиях; }{ }^{11} \text { Также в киевских евангелиях } 1697 \text { и } 1712 \text { гг; } \\
{ }^{12} \text { Также в киевских евангелиях } 1697 \text { и } 1712 \text { гг;; }{ }^{13} \text { Также в киевских евангелиях } 1697 \text { и } 1712 \text { гг;; }{ }^{14} \text { Также в киевских евангелиях } 1697 \\
\text { и } 1712 \text { гг. }\end{array}$} \\
\hline
\end{tabular}

Выше перечисленные отличия, выявленные в месяцесловах тетров 1644 и 1665 гг., позволяют отнести их к особой подгруппе старопечатных церковнославянских Евангелий периода XVII-XVIII веков.

Учитывая все выше перечисленные особенности месяцесловов старопечатных львовских церковнославянских тетроевангелий можно их разделить на три следующие группы:

- месяцесловы Евангелий 1636, 1670, 1690, 1704 и 1722 гг. как имеющие наименьшее количество разночтений между собой;

- месяцесловы Евангелий 1644 и 1665 гг. идентичные между собой и отличающееся от остальных львовских изданий;

- месяцеслов Евангелия 1743 г.

Месяцесловы львовской печати XVII-XVIII веков имеют в чем-то особенное сходство, в чем-то различие с месяцесловами Евангелий других типографий того же периода (киевской и почаевской) и, возможно, также послужили (дополнительными) подлинниками для более поздних печатных изданий богослужебной евангельской книги.

Проведенный сравнительно-текстологический анализ старопечатных Евангелий опровергает устоявшееся представление о единообразии их традиционного содержания $^{39}$ и позволяет говорить о формировании во Львове в XVII-XVIII веках собственной традиции печатного Евангелия, которая, наряду с другими, является неотъемлемой частью духовно-исторического наследия Церкви.

\footnotetext{
39 Жуковская, 1976, 353
} 


\section{Библиография}

Альберти А. (2016). Text und Textwert. Мюнстерская методика и оценка разночтений славянских евангелий. Studi Slavici XIII: 307-335.

Амфилохий архимандрит. (1882). Четверо-евангеліе Галичское 1144 года сличенное съ древле-Славянскими рукописными Евангеліями XI-XVII в. и печатными: Острожскимь 1571 и Кіевскимь 1788 г. сь греческимь евангелскимъ текстомъ 835 года. Т. І. Москва.

Амфилохий архимандрит. (1883). Четверо-евангеліе Галичское 1144 года сличенное съ древле-Славянскими рукописными Евангеліями XI-XVII в. и печатными: Острожскимъ 1571, Кутейнскимъ 1652 и Кіевскимъ 1788 г. съ греческимъ евангелскимъ текстомь 835 года. Т. II. Москва.

Бондар Н.П. (2015). Взаємовпливи кирилічних видань Свангелій другої половини XVI - середини XVII ст. вільнюського та львівського друку. W Науковий потенціал славістики: Історичні здобутки та тенденціі розвитку. Тези доповідей міжнародної наукової конферениії до дня слов'янської писемності і культури (Київ, 21 травня 2015 р.). Київ, 109-112.

Воскресенский Г.А. (1894). Евангеліе отъ Марка по основнымъ спискамъ четырехъ редакцій рукописнаго славянскаго евангельскаго текста съ разночтеніями изъ ста восьми рукописей Евангелія XI-XVI вв. Сергиевъ Посадъ.

Воскресенский Г.А. (1896). Характерическія черты четырехъ редакиій славянского перевода Евангелія отъ Марка по сто двенадиати рукописямъ Евангелія XI-XVI вв. Москва.

Дограмаджиева Е. (1993). Състав на славянските ръкописи четвероевангелия. Palaeobulgarica, XVII (2): 3-21.

Дограмаджиева Е. (2010). Месецословните четива в славянските ръкописни Евангелия (X-XVII в.). (=Кирилло-Методиевски Студии. Кн. 19). София.

Евангелие от Иоанна в славянской традиции (Novum Testamentum Palaeoslovenice I), изд. подготов. А.A. Алексеев, А.А. Пичхадзе, М.Б. Бабицкая, И.В. Азарова, Е.Л. Алексеева, Е.Л. Ванеева, А.М. Пентковский, В.А. Ромодановская, Т.В. Ткачева, Санкт-Петербургское Отделение Российского Библейского Общества - Славянский Библейский Фонд Российской Академии Наук, Санкт-Петербург 1998.

Евангелие от Матфея в славянской традиции (Novum Testamentum Palaeoslovenice II), изд. подготов. А.А. Алексеев, И.В. Азарова, Е.Л. Алексеева, М.Б. Бабицкая, Е.Л. Ванеева, А.А. Пичхадзе, В.А. Ромодановская, Т.В. Ткачева, Санкт-Петербургский Государственный Университет Филологический Факультет - Синодальная Библиотека - Российское Библейское Общество Санкт-Петербургское отделение, Санкт-Петербург 2005.

Жуковская Л.П. (1976). Текстология и язык древнейших славянских памятников. Москва.

Иванова Н.П. (2010). История изучения месяцесловов и их значение в исследованиях по древнерусской хронологии (XVII - начало XX вв.). Известия Алтайского государ- ственного университета. Серия История, политология. 4/1 (68/1): 108-114.

Исаевич Я.Д. (1962). Издательская деятельность Львовского братства в XVI-XVIII веках. Москва.

Лосева О.В. (1995). Месяцеслов Архангельского Евангелия 1092 г. W Архангельскому Евангелию 1092 года - 900 лет. Москва, 46-54.

Лосева О.В. (1999а). Месяцесловы древнерусских Евангелий XI-XII веков. Москва.

Лосева О.В. (1999b). Русские праздники в древнейших церковных календарях. Русское средневековье, 5-59.

Лосева О.В. (2001а). Русские месяцесловы XI-XIV веков. Москва.

Лосева О.В. (200b). Периодизация древнерусских месяцесловов XI - XIV в. Древняя Русь 4: 14-35.

Лосева О.В. (2003). Праздники Святогробского Типикона в русских календарях XI-ХІІ веков. Православный палестинский сборник, 100, 132-141.

Людоговский Ф.К. (2006). Функционирование и эволюция служебного и четьего вариантов церковнославянского Евангелия в эпоху книгопечатания: постановка проблемы. W Лингвистическое источниковедение и история русского языка 2004-2005. Москва, 400-418.

Сергий архиепископ (Спасскій). (1901). Полный месяцеслов Востока. Т. 1-2. Изд. 2. Владимиръ.

Тиховский Ю. Мнимая типография Почаевского монастыря (с к. XVI до 1-й четв. XVIII в.) Киевская старина, 1895, Том 50, Июль. - С. 1-35; Сентябрь. - С. 248-281.

Шустова Ю.Э. (2009). Документы Львовского Успенского Ставропигийского Братства 1586/1788. Москва.

Ostapczuk J. (2010). Cerkiewnosłowiański przekład liturgicznych perykop okresu Paschalnego i święta Pięćdziesiątnicy w rękopiśmiennych ewangeliarzach krótkich. Warszawa.

Ostapczuk J. (2011). Starodruki cyrylickich ewangeliarzy w świetle cerkiewnosłowiańskiej tradycji. Rocznik Teologiczny 53(1-2): 87-106.

Ostapczuk J. (2013). Sobotnie i niedzielne perykopy liturgiczne $z$ Ewangelii Mateusza w cerkiewnostowiańskich lekcjonarzach krótkich. Warszawa.

Ostapczuk J. (2014). Stabilność cerkiewnosłowiańskiego tekstu Ewangelii w cyrylickich starych drukach lekcjonarzy. W Starodruki cyrylickie w zasobach parafialnych pogranicza polsko-stowackiego. Konferencja realizowana w ramach obchodów 1000 rocznicy śmierci i 20 rocznicy kanonizacji św. Maksyma Gorlickiego (Sandowycza). Gorlice, 10-24.

Ostapczuk J. (2016a). Menologion kijowskiego ewangeliarza pełnego z 1707 roku (uwagi wstępne na przykładzie miesiąca wrzesień). ELPIS 18: 65-73.

Ostapczuk J. (2016b). Евангелие от Матфея в старопечатных изданиях Четвероевангелий: предварительные замечания. W Современные проблемы археографии. Выпуск 2: Сборник статей по материалам конференции к 300-летию Библиотеки Российской академии наук 21-24 октября 2014 г. Ред. колл. Н.Ю. Бубнов, М.А. Вознесенская, В.А. Клишева, М.В. Корогодина, Ф.В. Панченко, 
В.Г. Подковырева. Отв. ред. И.М. Беляева. Сост. М.В. Корогодина. Санкт Петербург, 275-286.

Ostapczuk J. (2017a). Евангелие от Марка в старопечатных изданиях Четвероевангелий. Доклад прочитанный на Международной научной конференции, посвященной 510-летию создания Библейского сборника Матфея Десятого «Славянская Библия в эпоху раннего книгопечатания». Институт Русской Литературы (Пушкинский Дом) РАН, Библиотека Российской Академии Наук; 1317 VI 2017 г., Санкт-Петербург.

Ostapczuk J. (2017b). O liczbie cyrylickich starych druków tetraewangelii ze Lwowa, ELPIS 19: 181-189;
Kurianowicz M. (2005). Соотношение старославянских и древнерусских черт в Яблочинском евангелии - памятнике XVIII века. Studia Wschodniostowiańskie 5: 287302 ;

Kurianowicz M. (2010) Словообразовательные отличия русского церковнославянского языка от старославянского языка на материале евангелия XVIII века. Дублеты. Studia Wschodniosłowiańskie 10: 127-131.

Kurianowicz M. (2012). Ewangeliarz z 1771 r. jako zabytek płd.-wsch. Polski. Analiza Tekstologiczna - inwersja. Prace językoznawcze XIV: 167-176.

Rozmiar artykułu: 0,8 arkusza wydawniczego 


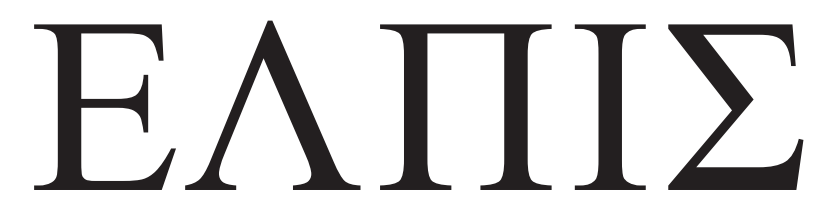

CZASOPISMO TEOLOGICZNE KATEDRY TEOLOGII PRAWOSŁAWNEJ UNIWERSYTETU W BIAŁYMSTOKU

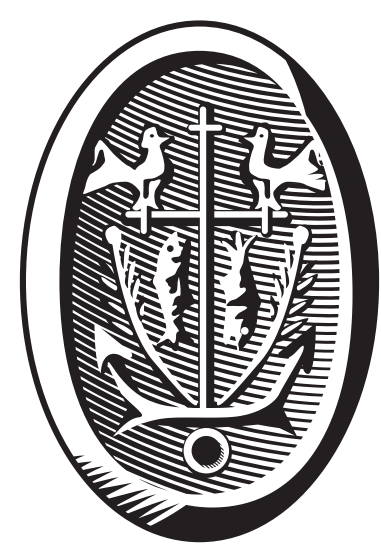

ADRES REDAKCJI

ul. Ludwika Zamenhofa 15, 15-435 Białystok, Polska tel. 85 745-77-80, e-mail: elpis@uwb.edu.pl www.elpis.uwb.edu.pl 